\title{
Influence of formative assessment on summative assessment in undergraduate medical students
}

\author{
Dr. Nazma Begum ${ }^{\prime}$, Prof. Sakhawat Hossain ${ }^{2}$, Prof. Dr. Md. Humayun Kabir Talukder ${ }^{3}$
}

\begin{abstract}
This cross sectional descriptive study was carried out to determine the students' view about the influence of formative assessment on summative assessment The study was carried out from July 2009 to June 2010 over 300 intern doctors of Medicine and Paediatrics department of two government and two private medical colleges. Data were collected through self administered questionnaire. The questionnaire included different opinion about the influence of formative assessment on summative assessment and were rated using the 5 point Likert's scale. This study revealed that feedback from formative assessment to the students is important to supplement and modify teaching by the teachers. Students' fear is for summative assessment is reduced by formative assessment Written test, VIVA/SOE and OSCE/OSPE of formative assessment greatly improves the results of summative assessment Students opined that to improve the formative assessment the number of teachers should be increased, teachers should be trained up, teachers should give more time to the students and optimum feedback should be provided to the students. Frequency of formative assessment should remain as it is. Twenty to twenty five percent marks from formative assessment should be added to the summative assessment.
\end{abstract}

Key Words: Formative assessment. Summative assessment, Teacher, Medical students

\section{Introduction}

Assessment is important in all forms of learning. Michael Serven coined the terms formative and summative evaluation and emphasized their differences both in terms of the goals of the information they seek and how the information is used. ${ }^{1}$ Bloom B just a year later made formative assessment a keystone of learning for Mastery. ${ }^{2}$ $\mathrm{He}$, along with Thomas Hasting ${ }^{3}$ and George Madaus ${ }^{3}$ produced the Handbook of Formative and Summative Evaluation and showed how formative assessments could be linked to instructional units in a variety of content areas. According to Kellough and Kellough "Teaching and learning are reciprocal processes that depend on and affect one another. Thus, the assessment component deals with how well the students are learning and how well the teacher is teaching". ${ }^{4}$ Formative assessment is the assessment that takes place during a course or programming of study, as an integral part of the learning process. It is often informal. Summative assessment is normally carried out at or towards the end of a course it is always a formal process, and it is used to see if learners have acquired the skills, knowledge, behavior or understanding that the course set out to provide them with. It gives an overall picture of performance. Formative

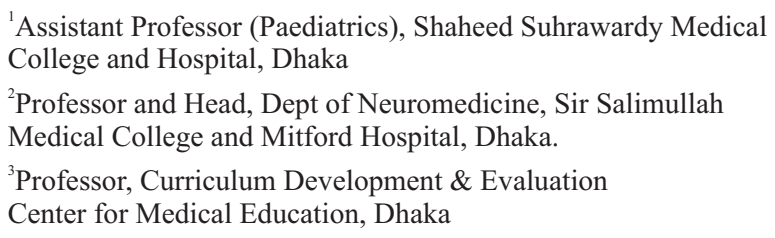

Address of correspondence: Dr. Nazma Begum

Asst. Prof., (Paediatrics), Shaheed Suhrawardy Medical College and Hospital, Dhaka

E-mail: nazmabegum29@ymail.com Cell: 01819242374 assessment is the assessment of for learning and summative assessment is the assessment of learning. The MBBS curriculum 2002 in Bangladesh has introduced MCQs, SOE $\&$ OSPEs/OSCEs based. This curriculum includes formative assessrment that is item test, card final, term final, block posting etc and summative examinations that is final professional examination. Provision for adding 10\% marks from formative assessrment to summative assessment has been introduced. So, it was high time to evaluate the actual effect of formative assessment on summative assessment under present curriculum in Bangladesh. The aim of this study was to determine the students view about the influence of formative assessment on summative assessment.

\section{Methods}

This cross sectional type of descriptive study was carried out in 2 public medical colleges (Dhaka Medical College and Sir Salimullah Medical College) and 2 private medical colleges (Bangladesh Medical College and Holy Family Red Crescent Medical College) in Dhaka city from July 2009 to June 2010. A structured questionnaire reflecting the influence of formative assessment on summative assessment was prepared. Pre-testing was done on 20 intern doctors from Shaheed Suhrawardy Medical College and accordingly data was collected and modified. Permission from the respective college authorities (principles) were formally sought beforehand. A questionnaire for students were prepared to pass their comment in the different aspect of 'the influence' of formative assessment on summative assessment. The questionnaire included different statement about the influence of formative assessment on summative and rated using 5 point Likert scale. Questionnaires were distributed to all the intern doctors of the Medicine department of those respective institutes. Three hundred intern doctors working in the department of Medicine of

Bangladesh Journal of Medical Education 2013;4(1):16-19. (C) 2013 Begum et al., publisher and licensee Association for Medical Education. This is an Open Access article which permits unrestricted non-commercial use, provided the original work is properly cited. 
those selected medical colleges who were willing to participate were included in the study as respondents. Purpose of the study was duly explained to the respondent. Information and identity of the respondent were kept confidential. Completed data and questionnaire were collected, edited, processed and analyzed by using SPSS computer package. If necessary some data were handled manually with the help of calculator and Microsoft Excel program.

\section{Result}

Among the respondent 199 (49\%) intern doctors were from government medical colleges and 101(24.9\%) intern doctors were from non-government medical colleges. Table I shows that $86(28.8 \%)$ intern doctors strongly agreed and $151(50.5 \%)$ intern doctors agreed that formative assessment greatly influence the results of summative assessment. Seventy six (25.3\%), 149(49.7\%) intern doctors strongly agreed and agreed respectively in their opinion regarding the teachers impression about a student from formative assessment influences the results of summative assessment. On the contrary 26(8.7\%) intern doctors disagreed in this aspect (Table II). Seventy percent of the intern doctors (strongly agreed 25\%, agreed $44.3 \%$ ) considered that students fear for Summative exam is reduced by formative assessment (Table III). Among the respondents 75(25\%), $152(50.6 \%)$ intern doctors strongly agreed and agreed respectively in their opinion that teachers feedback to students of formative exam is helpful for better performance in summative exam ( Table IV). Among the respondents $97(32.4 \%)$ strongly agreed that written test of formative assessment greatly improves the results of summative assessment where as $120(40 \%)$ intern doctors agreed and $21(7 \%)$ intern doctors disagreed (Table V). One hundred nine $(36.3 \%)$ and $117(39 \%)$ intern doctors strongly agreed that Viva/SOE and OSCE/OSPE of formative assessment greatly improves the results of summative assessment (Table VI and VII). Respondents made suggestion in different aspects to improve formative assessment to make a positive impact on summative assessment (Table VIII). Figure I shows most intern doctors want to add less than $25 \%$ marks (Mean \pm SD $22.38 \pm 15.84$ ) to be added from formative assessment to summative assessment.

Table 1: Distribution of respondents by their opinions about the statement that the results of formative assessment greatly influence the results of summative assessment

\begin{tabular}{lcc}
\hline \multirow{2}{*}{ Different Level of opinion } & \multicolumn{2}{c}{ Intern Doctors } \\
& Frequency & $\%$ \\
\hline Strongly Disagree & 12 & $4 \%$ \\
Disagree & 22 & $7 \%$ \\
Neither agree nor disagree & 29 & $9.7 \%$ \\
Agree & 151 & $50.5 \%$ \\
Strongly Agree & 86 & $28.8 \%$ \\
Total & 300 & $100 \%$ \\
\hline
\end{tabular}

Table 2: Distribution of respondents by their opinions about the statement that the teachers' impression about a student from formative assessment influences the results of summative assessment

\begin{tabular}{lcc}
\hline Different Level of opinion & \multicolumn{2}{c}{ Intern Doctors } \\
& Frequency & $\%$ \\
\hline Strongly Disagree & 6 & $2 \%$ \\
Disagree & 26 & $8.7 \%$ \\
Neither agree nor disagree & 43 & $14.3 \%$ \\
Agree & 149 & $49.7 \%$ \\
Strongly Agree & 76 & $25.3 \%$ \\
Total & 300 & $100 \%$ \\
\hline
\end{tabular}

Table 3: Distribution of respondents by their opinions about the statement that students fear for summative exam is reduced by formative exam

\begin{tabular}{lcc}
\hline \multirow{2}{*}{ Different Level of opinion } & \multicolumn{2}{c}{ Intern Doctors } \\
& Frequency & $\%$ \\
\hline Strongly Disagree & 15 & $5 \%$ \\
Disagree & 24 & $8 \%$ \\
Neither agree nor disagree & 53 & $17.7 \%$ \\
Agree & 133 & $44.4 \%$ \\
Strongly Agree & 75 & $25 \%$ \\
Total & 300 & $100 \%$ \\
\hline
\end{tabular}

Table 4: Distribution of the respondents by their opinion about the statement that teachers' feedback to students of formative exam is helpful for better performance in summative exam

\begin{tabular}{lcc}
\hline \multirow{2}{*}{ Different Level of opinion } & \multicolumn{2}{c}{ Intern Doctors } \\
& Frequency & $\%$ \\
\hline Strongly Disagree & 5 & $1.7 \%$ \\
Disagree & 22 & $7.3 \%$ \\
Neither agree nor disagree & 46 & $15.3 \%$ \\
Agree & 152 & $50.6 \%$ \\
Strongly Agree & 75 & $25 \%$ \\
Total & 300 & $100 \%$ \\
\hline
\end{tabular}

Bangladesh Journal of Medical Education 2013;4(1):16-19. 
Table 5: Distribution of the respondents by their opinion about the statement that written test of formative assessment greatly improves the results of summative assessment

\begin{tabular}{lcc}
\hline \multirow{2}{*}{ Different Level of opinion } & \multicolumn{2}{c}{ Intern Doctors } \\
& Frequency & $\%$ \\
\hline Strongly Disagree & 16 & $5.3 \%$ \\
Disagree & 21 & $7 \%$ \\
Neither agree nor disagree & 46 & $15.3 \%$ \\
Agree & 120 & $40 \%$ \\
Strongly Agree & 97 & $32.4 \%$ \\
Total & 300 & $100 \%$ \\
\hline
\end{tabular}

Table 6: Distribution of the respondents by their opinion about the statement that viva/SOE of formative assessment greatly improves the results of summative assessment

\begin{tabular}{lcc}
\hline \multirow{2}{*}{ Different Level of opinion } & \multicolumn{2}{c}{ Intern Doctors } \\
& Frequency & $\%$ \\
\hline Strongly Disagree & 7 & $2.3 \%$ \\
Disagree & 14 & $4.7 \%$ \\
Neither agree nor disagree & 35 & $11.7 \%$ \\
Agree & 135 & $45 \%$ \\
Strongly Agree & 109 & $36.3 \%$ \\
Total & 300 & $100 \%$ \\
\hline
\end{tabular}

Table 7: Distribution of the respondents by their opinion about the statement that OSCE/OSPE of formative assessment greatly improves the results of summative assessment

\begin{tabular}{lcc}
\hline \multirow{2}{*}{ Different Level of opinion } & \multicolumn{2}{c}{ Intern Doctors } \\
& Frequency & $\%$ \\
\hline Strongly Disagree & 7 & $2.3 \%$ \\
Disagree & 20 & $6.7 \%$ \\
Neither agree nor disagree & 36 & $12 \%$ \\
Agree & 120 & $40 \%$ \\
Strongly Agree & 117 & $39 \%$ \\
Total & 300 & $100 \%$ \\
\hline
\end{tabular}

Table 8: Distribution of the respondents by their opinion about the statement that how the formative assessment can be improved to make a positive impact on summative assessment

\begin{tabular}{lccc}
\hline \multicolumn{1}{c}{ Event } & $\begin{array}{c}\text { Different Level } \\
\text { of opinion }\end{array}$ & \multicolumn{2}{c}{ Intern Doctors } \\
& & Frequency & $\%$ \\
\hline $\begin{array}{l}\text { No. of teachers } \\
\text { should be Increased }\end{array}$ & Yes & 142 & $47.2 \%$ \\
$\begin{array}{l}\text { Teachers should be } \\
\text { trained up }\end{array}$ & Yes & 158 & $52.8 \%$ \\
$\begin{array}{l}\text { Teachers should give } \\
\text { more time to students }\end{array}$ & Yes & 198 & $66 \%$ \\
$\begin{array}{l}\text { Frequency of formative } \\
\text { assessment should be }\end{array}$ & Yes & 190 & $63.3 \%$ \\
increased & & 236 & $36.7 \%$ \\
$\begin{array}{l}\text { Frequency of formative } \\
\text { assessment should be }\end{array}$ & Yes & 96 & $31.3 \%$ \\
decreased & & 204 & $68 \%$ \\
$\begin{array}{l}\text { Optimum feedback of } \\
\text { formative assessment } \\
\text { should be given to the }\end{array}$ & Yes & 196 & $65.4 \%$ \\
students & & 104 & $34.6 \%$ \\
$\begin{array}{l}\text { Optimum feedback of } \\
\text { formative assessment } \\
\text { should be given to the } \\
\text { teachers to make the } \\
\text { teaching more effective }\end{array}$ & Yes & 152 & $50.6 \%$ \\
\hline
\end{tabular}

Figure 1: Intern doctors' view about the statement that what percentage of marks of formative assessment should be added with summative assessment

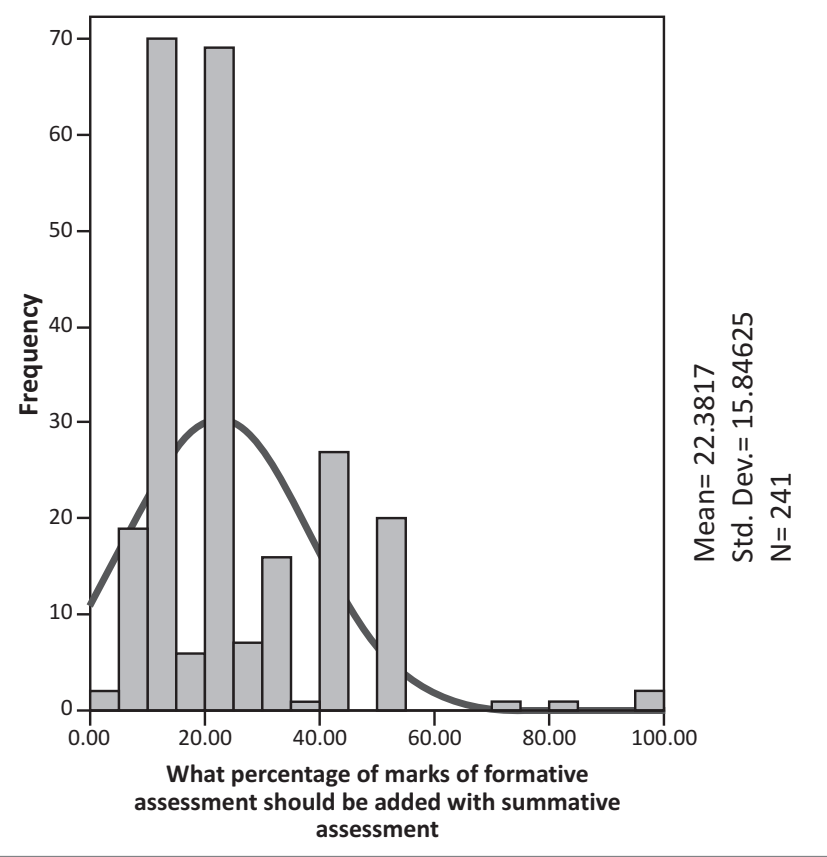

Bangladesh Journal of Medical Education 2013;4(1):16-19. 


\section{Discussion}

Among 300 intern doctors 86(28.8\%) and 151 (50.3\%) strongly agreed and agreed respectively that the results of formative assessment greatly influences the results of summative assessment. A study conducted by Olson \& McDonald found that students scored higher in summative examination who took part in formative examinations 5 . Seventy five percent (strongly agreed $25.3 \%$ and agreed $49.7 \%$ ) of intern doctors considered that teachers' impression about a student from formative assessment influences the result of summative assessment. Majority of intern doctors that is $70 \%$ (strongly agreed $25 \%$ and agreed $44.3 \%$ ) were in agreement with the issue that students fear for summative exam is reduced by formative exam. This study consistent with the finding of Khan $\mathrm{KS}^{6}$ Majority of the intern doctors that is $76 \%$ (strongly agreed $25 \%$ and agreed $50.7 \%$ ) opined that Teachers feedback to of formative exam to students is helpful for better performance in summative exam' whereas $9 \%$ intern doctors (disagree $7.3 \%$ and strongly disagreed $1.7 \%$ ) were against in their opinion. Charman \& Elmes have shown that feedback enhance students' performance'. Majority of the research reports on formative assessment have mentioned that the feedback is most important issues in formative assessment, in other word without feedback formative assessment are useless. ${ }^{8,910}$ Majority of the intern doctors that is $72 \%$ (strongly agreed $32.4 \%$ and agreed $40 \%$ ) supported written test of formative assessment to improve the results of summative assessment and $12.3 \%$ intern doctors (disagree $7 \%$ and strongly disagreed $5.3 \%$ ) differed in their opinion.

Eighty one percent (strongly agreed $36.3 \%$ and agreed $45 \%$ ) of intern doctors supported Viva/SOE and 79\% (strongly agreed $39 \%$ and agreed $40 \%$ ) supported OSCE/OSPE of formative assessment to improve the results of summative assessment. Among 300 interns 142 (47.2\%) considered that number of teachers should increase and $198(66 \%)$ interns opined that the teachers should be trained up to improve the formative assessment to make a positive impact on summative assessment. In a study conducted by Khan KS find $70 \%$ of the teachers mentioned that number of teachers are inadequate in medical colleges ${ }^{6}$. Similar was the finding by Harden. ${ }^{11}$ Two hundred and thirty six $\quad(78.7 \%)$ interns were against to increase and $204(68 \%)$ were against to decrease the frequency of formative assessment. This study clearly indicates that the frequency of present formative assessment status should not be altered. One hundred and fifty two (50.6\%) supported and 148 (49.4\%) disagreed with the opinion that optimum feedback should be given to the teachers to make the teaching more effective. This study indicates that the intern doctors are not fully aware of the powerful impact of feedback to the teachers for better teaching learning session. A study was conducted by $\mathrm{Vag}^{12}$ to find out areas required revision after administering formative exercise. It also provides important feedback to the teachers to evaluate their efficacy and to identify the areas which need re-emphasis or require an alternative strategy. Respondents viewed 25\% (mean 28.38) marks of formative assessment should be added with summative assessment.

\section{Conclusion}

This study was designed to explore the students' view about the influence of formative assessment on summative assessment in undergraduate course. The study revealed that formative assessment has got significant effect on summative assessment in various aspects. Feedback from formative assessment to both students and teachers plays an important role in teaching-learning processes. The student's fear for summative exam is markedly reduced by facing formative assessment. Teachers' impression about a student from formative assessment affects the results of summative exam. Teachers should be trained up and numbers should be increased. Teachers should be motivated to give more time to students and proper feedback should be given to the teachers for adopting adequate measures to supplement teaching.

\section{References}

1. Wikipedia foundation. Formative assessment 2008; http;//en.wikipedia.org/wiki/Formative_Assessment

2. Bloom, Benjamin S. Learning for mastery. Los Angeles, USA: University of California press, 1968.

3. Hastings T. and Madaus, G. Handbook of formative and summative evaluation of student learning, New York: McGraw-Hill, 1971.

4. Kellough RD, Kellogg NG. Secondary school teaching: A guide to methods and resources: Planning for competence. Copyright by Prentice Hill, New Jersey, 1999.

5. Olson BI, Macdonald JI. Influence of online formative assessment upon student learning in biomedical science courses. Journal of Dental Education 2004; 6(6): 656-59.

6. Khan KS, Vies DA, Gupta K .Formative self assessment using multiple true false questions on the Internet: feedback according to confidence about correct knowledge. .Medical Teacher 2001; 23 (2):158- 63.

7. Chairman D, Elmes A. A computer based formative assessment strategy for a basic statistics module in geography. Journal of geography in Higher education 1998; 65(3):381-385.

8. Chappius S, Chappius J. The best value in formative assessment, Informative Assessment 2007; 65 (4): 1-4.

9. Black P, William D. Inside the black box: raising standards through classroom assessment. Phi Delta Kappan 2008; 80:139-149.

10. Rushton A. Formative assessment: A key to deep learning? Medical Teacher 2005; 27(6): 509-13.

11. Harden RM . Stress, pressure and burnout in teachers: is the swan exhausted? Medical Teacher 1999; 21(.3): $245-47$.

12. Vag M, Avadhhany ST \& Rao BS. Student perspective on the role of formative assessment in physiology. Medical Teacher 1996; 18(4):324 - 26. 